\title{
A First Look at the Foundation and Corporate Response to the Economic Crisis
}

\section{By Steven Lawrence, Senior Director of Research}

Unlike most natural or humanitarian disasters, the impact of the current economic downturn is not bound by time or place and has affected donors as well as those needing their assistance. Despite the loss of philanthropic resources inflicted by this still unfolding crisis, a growing number of grantmakers have expressed their willingness to take exceptional measures to address the new challenges that have arisen. The Foundation Center has tracked and mapped online close to 50 foundations and corporations that have already announced over $\$ 100$ million in grants and program-related investments for efforts ranging from reducing the number of foreclosures to shoring up food banks and services for the homeless to providing financial counseling.

An examination of the support provided by these initial responders suggests that they are focusing strongly-but by no means exclusively_on addressing the impact of the economic crisis in their home communities. Consistent with this observation, community foundations appear to be playing a critical role in responding to the increased need within their geographic areas. Their extensive local knowledge, combined with their willingness to serve as intermediaries for both individual and institutional giving, makes them especially valuable in the current situation. Yet, it is also important to note that a number of these institutional donors, especially corporate funders, have directed their economic crisis-response support nationally.
Mapping the Safety Net in Real Time

The Foundation Center is constantly monitoring and collecting the most recent data on U.S. foundation and corporate support in response to the economic crisis. This information is easily accessed at foundationcenter.org on an interactive map displaying grants and program-related investments (PRIs), which is updated weekly and supplemented by a daily RSS grant feed. To submit grants data for inclusion, please contact Matthew Ross, Manager of Special Data Projects, at mr@foundationcenter.org.

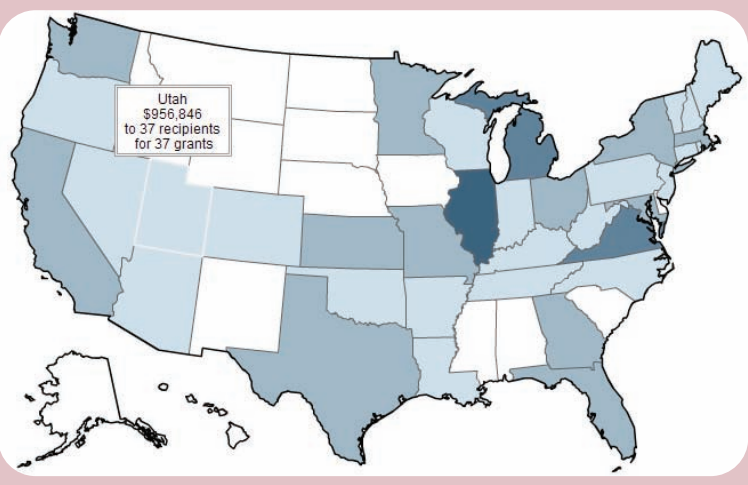


Beyond the specific efforts highlighted below, many foundations and corporations will be responding to the economic crisis in a less visible but equally critical way. These funders will strive to maintain stable levels of giving-or minimize reductions in funding - despite pronounced losses in income and the value of their assets. The Cleveland, Ohio-based George Gund Foundation, for example, will do this by reducing its operating costs and increasing the amount it pays out relative to its assets.

\section{INSTITUTIONAL DONORS RESPOND}

Given the relatively small number of foundations and corporations that have publicly announced new commitments specifically related to the economic crisis thus far, it is not yet possible to make definitive statements about the institutional donor response. Nonetheless, an examination of the data we've gathered so far does begin to illustrate the range of approaches they are taking.

\section{Helping to Stop Foreclosures}

Considering the central role of subprime mortgage foreclosures and the loss of confidence in the financial instruments that packaged these mortgages, it is not surprising that more than half of foundation and corporate dollars committed so far in response to the economic crisis focus on housing issues. The Illinois-based John D. and Catherine T. MacArthur Foundation has committed just over $\$ 38$ million to address the challenges facing both homeowners and renters in the Chicago area, including three program-related investments (PRIs) totaling \$34 million. The largest of these PRIs was a $\$ 15$ million lowinterest deposit for the ShoreBank
Corporation's $\$ 100$ million Rescue Loan and Prevention Program, which seeks to save homeowners from foreclosures. MacArthur's largest grant was a $\$ 2.5$ million award to Neighborhood Housing Services of Chicago for public education and counseling to prevent foreclosures in selected Chicago neighborhoods as part of the organization's Foreclosure Prevention and Mitigation Project. Among other funders that have provided support specifically addressing the foreclosure crisis are the Bank of America Charitable, Boston, Citi, Ford, George Gund, Kresge, Skillman, Surdna, and Raymond John Wean foundations, Countrywide Home Loans, Inc. Corporate Giving Program, and the New York Community Trust.

\section{Providing Emergency Assistance}

Offering support to meet the basic needs of area residents has been a primary focus of many early responders to the economic crisis, especially community foundations. From the Boston Foundation and the Community Foundation for the National Capital Region in the East to the Greater Cincinnati and Central Minnesota community foundations in the Midwest to the Marin and Silicon Valley community foundations in the West, the majority of community foundations included in the initial group of funders have provided support for emergency heat, rent, and/or utilities assistance. Many have also funded emergency food assistance. Yet, this type of funding did not come solely from community foundations. For example, the Arizona-based Virginia G. Piper Charitable Trust awarded three grants totaling $\$ 50,000$ to support meal services at the Association of Arizona Food Banks, Andre House of Arizona, and Paz de Cristo Community Center as part of its Community Relief Grants Program.

\section{Economic Crisis Response: Leading Foundation and Corporate Donors}

\begin{tabular}{|c|c|c|c|c|}
\hline Foundation & State & Donor Type ${ }^{1}$ & Amount & No. \\
\hline John D. and Catherine T. MacArthur Foundation & IL & IN & $\$ 38,050,000$ & 8 \\
\hline Ford Foundation & NY & IN & $15,719,000$ & 18 \\
\hline Bank of America Charitable Foundation & NC & CS & $10,627,500$ & 81 \\
\hline GE Foundation & $\mathrm{CT}$ & CS & $10,500,000$ & 1 \\
\hline Health Care Foundation of Greater Kansas City & $\mathrm{MO}$ & PC & $6,950,000$ & 51 \\
\hline $\begin{array}{l}\text { Countrywide Home Loans, Inc. Corporate Giving } \\
\text { Program }^{2}\end{array}$ & $\mathrm{CA}$ & CG & $4,850,000$ & 15 \\
\hline Wal-Mart Foundation & AR & CS & $4,400,000$ & 7 \\
\hline Cargill, Incorporated Corporate Giving Program & $\mathrm{MN}$ & CG & $3,000,000$ & 4 \\
\hline Silicon Valley Community Foundation & $\mathrm{CA}$ & $\mathrm{CM}$ & $2,999,200$ & 47 \\
\hline Alfred P. Sloan Foundation & NY & IN & $2,728,613$ & 4 \\
\hline Kresge Foundation & MI & IN & $1,750,000$ & 2 \\
\hline Bill \& Melinda Gates Foundation & WA & IN & $1,400,000$ & 3 \\
\hline Jessie Ball duPont Fund & $\mathrm{FL}$ & IN & $1,000,000$ & 2 \\
\hline UJA-Federation of New York & NY & $\mathrm{PC}$ & $1,000,000$ & 2 \\
\hline New Hampshire Charitable Foundation & $\mathrm{NH}$ & $\mathrm{CM}$ & 993,964 & 18 \\
\hline Boston Foundation & MA & $\mathrm{CM}$ & 970,000 & 16 \\
\hline Marin Community Foundation & $\mathrm{CA}$ & $\mathrm{CM}$ & 960,000 & 17 \\
\hline United Way of Salt Lake & UT & $\mathrm{PC}$ & 956,846 & 37 \\
\hline California Community Foundation & $\mathrm{CA}$ & $\mathrm{CM}$ & 879,275 & 4 \\
\hline Michael \& Susan Dell Foundation & TX & IN & 825,000 & 33 \\
\hline Hartford Foundation for Public Giving & CT & $\mathrm{CM}$ & 697,000 & 4 \\
\hline $\begin{array}{l}\text { Community Foundation for the National Capital } \\
\text { Region }\end{array}$ & DC & $\mathrm{CM}$ & 535,000 & 43 \\
\hline Citi Foundation & NY & CS & 500,000 & 1 \\
\hline \multicolumn{5}{|c|}{$\begin{array}{l}\text { Source: The Foundation Center, 2009. Figures based on grants and program-related investments announced through January } 12 \text {, } \\
2009 \text {. Includes foundations and corporations reporting at least } \$ 500,000 \text { in commitments in response to the economic crisis. } \\
1 \mathrm{IN}=\text { independent foundation; } \mathrm{CS}=\text { corporate foundation; } \mathrm{CG}=\text { corporate giving program; CM = community foundation; } \\
\mathrm{PC}=\text { grantmaking public charity }\end{array}$} \\
\hline
\end{tabular}


Providing shelter and services for the homeless and those at risk of becoming homeless also captured a notable share of the support offered so far. The Connecticut-based GE Foundation made the single largest commitment in this area: a $\$ 10.5$ million grant to the United Way of America for homeless shelters and other organizations that meet basic needs. Among other support, the Connecticut-based Hartford Foundation for Public Giving awarded a $\$ 221,000$ grant to the Chrysalis Center to provide support services for homeless veterans, while the Community Foundation for the National Capital Region made a $\$ 15,000$ grant to the National Law Center on Homelessness and Poverty for work ensuring that systems are better equipped to address the needs of the homeless, as well as families at risk of becoming homeless.

Finally, support for emergency needs also extended to animals, with the Humane Society of the United States awarding grants through its Financial

\section{Economic Crisis Response: Leading Recipients of Foundation and Corporate Donors}

\begin{tabular}{|c|c|c|c|}
\hline Recipient & State & Amount & No. \\
\hline Shorebank Corporation & IL & $\$ 15,000,000$ & 1 \\
\hline Neighborhood Housing Services of Chicago & $\mathrm{IL}$ & $12,500,000$ & 3 \\
\hline United Way of America & VA & $10,500,000$ & 1 \\
\hline Local Initiatives Support Corporation & IL & $10,000,000$ & 1 \\
\hline Feeding America & $\mathrm{IL}$ & $4,575,000$ & 4 \\
\hline $\begin{array}{l}\text { Living Cities: The National Community } \\
\text { Development Initiative }{ }^{1}\end{array}$ & NY & $4,000,000$ & 2 \\
\hline Detroit Economic Growth Foundation & $\mathrm{Ml}$ & $3,250,000$ & 3 \\
\hline Consumer Credit Counseling Service of Greater Atlanta & GA & $2,600,000$ & 4 \\
\hline Acorn Housing Corporation & IL & $2,285,000$ & 3 \\
\hline Shorebank Enterprise Detroit & $\mathrm{Ml}$ & $2,000,000$ & 1 \\
\hline Neighborhood Reinvestment Corporation & DC & $1,700,000$ & 2 \\
\hline Center for New York City Neighborhoods & NY & $1,450,000$ & 6 \\
\hline Homeownership Preservation Foundation & MN & $1,250,000$ & 2 \\
\hline Community Foundation in Jacksonville & $\mathrm{FL}$ & $1,000,000$ & 2 \\
\hline Enterprise Community Partners & MD & $1,000,000$ & 1 \\
\hline Global FoodBanking Network & $\mathrm{IL}$ & $1,000,000$ & 1 \\
\hline Metropolitan Council on Jewish Poverty & NY & $1,000,000$ & 2 \\
\hline Public Broadcasting Service & VA & $1,000,000$ & 1 \\
\hline National Foundation for Credit Counseling & MD & 950,000 & 2 \\
\hline Food Lifeline & WA & 900,000 & 1 \\
\hline Legal Services of South Central Michigan & MI & 880,000 & 1 \\
\hline Enterprise Community Partners & TX & 750,000 & 2 \\
\hline Meals on Wheels Association of America & VA & 750,000 & 1 \\
\hline University of Pennsylvania & PA & 733,318 & 1 \\
\hline United Way & $\mathrm{CA}$ & 600,000 & 1 \\
\hline National Bureau of Economic Research & MA & 588,800 & 1 \\
\hline Legal Assistance Foundation of Metropolitan Chicago & IL & 550,000 & 2 \\
\hline California Reinvestment Coalition & $\mathrm{CA}$ & 500,000 & 1 \\
\hline Center for Responsible Lending & NC & 500,000 & 1 \\
\hline City First Enterprises & DC & 500,000 & 1 \\
\hline Community Housing Land Trust of Rhode Island & $\mathrm{RI}$ & 500,000 & 1 \\
\hline Local Initiatives Support Corporation & NY & 500,000 & 1 \\
\hline Local Initiatives Support Corporation, Twin Cities & MN & 500,000 & 1 \\
\hline Massachusetts Housing Investment Corporation & MA & 500,000 & 1 \\
\hline National Community Reinvestment Coalition & DC & 500,000 & 1 \\
\hline Neighborhood Progress & $\mathrm{OH}$ & 500,000 & 1 \\
\hline Salvation Army of Minneapolis & MN & 500,000 & 1 \\
\hline Second Harvest Heartland & MN & 500,000 & 1 \\
\hline
\end{tabular}

Source: The Foundation Center, 2009. Figures based on grants and program-related investments announced through January 12,2009 . Includes recipients benefiting from at least $\$ 500,000$ in commitments.

${ }^{1}$ Living Cities, listed here as a recipient of foundation support, has itself made eight grants in response to the economic crisis totaling $\$ 4$ million, which are included in the Foundation Center's interactive map of economic crisis response funding.

Crisis Pet Fund, which was created in response to reports from shelters of a marked rise in the number of families who could not afford to keep or feed their pets. The Foundation Center has so far tracked 44 grants totaling nearly $\$ 78,000$ made through this fund.

\section{Understanding Why It Happened}

The economic downturn currently has no clear end in sight, but that has not kept several foundations from supporting efforts to understand how the crisis came about and ensure that it does not happen again. For example, the Alfred P. Sloan Foundation has provided three grants totaling $\$ 1.7$ million to the Wharton School at the University of Pennsylvania, the National Bureau of Economic Research, and the Brookings Institution to study the ongoing financial market crisis and to improve public understanding of economics and finance. The foundation made an additional $\$ 1$ million grant to the NewsHour with Jim Lehrer for a series of reports on the crisis, with the same goal of improving the public's economic and financial literacy. The Ford Foundation, through a $\$ 300,000$ grant to the Levy Economics Institute at Bard College, has funded a study to research the nature and dynamics of the current financial crisis and generate a new regulatory framework to address it. The Citi Foundation has also provided support to underwrite national work to develop data on the crisis.

\section{Shoring Up Current Grantees}

Most of the support provided by the close to 50 foundation and corporate donors examined for this advisory targeted emergency relief efforts or initiatives that address the cause of the current crisis. However, one funderthe Texas-based Michael \& Susan Dell Foundation, took a somewhat different approach. In November 2008, the 
foundation awarded 33 one-time, "surprise" grants of $\$ 25,000$ each to organizations working to improve the lives of children in the Central Texas area, to recognize their work and help them fill unexpected gaps in their operating budgets. As the economic crisis continues in 2009, this type of grant may become more common.

\section{WHAT COMES NEXT}

The Foundation Center will continue collecting and analyzing the exceptional commitments made by foundations, corporations, and other institutional donors in response to the crisis, with a goal of providing the most current, comprehensive record available. We encourage grantmakers to supply us with detailed information on their efforts in this area so that we can incorporate it into our upcoming research on this subject.

In the coming months, the Center will also release findings from a national survey of U.S. foundations on the impact of the downturn on their grantmaking and the latest edition of Foundation Growth and Giving Estimates, which will offer perspective on the outlook for foundation giving in 2009 and 2010.
Economic Crisis Response: Foundation and
Corporate Commitments by Major Subject
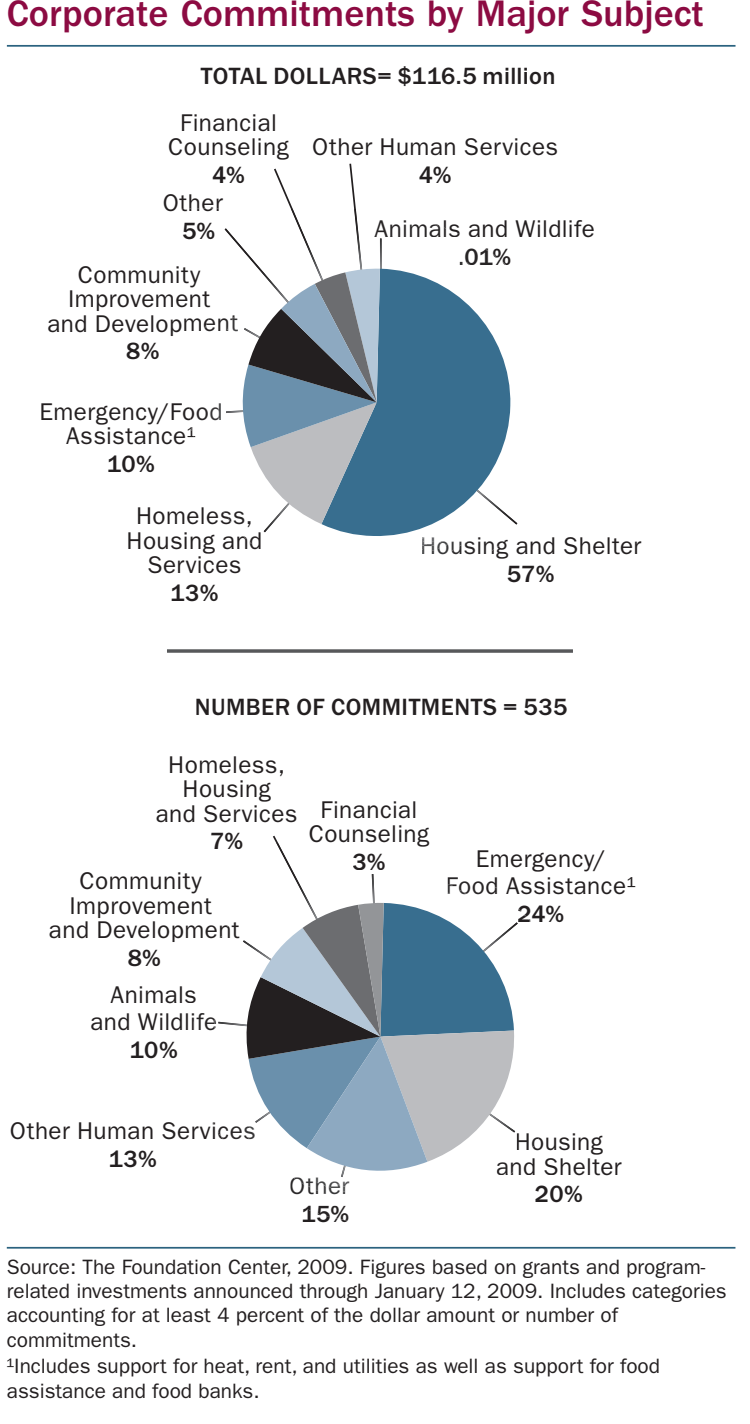

\section{About the Foundation Center}

Established in 1956, and today supported by close to 600 foundations, the Foundation Center is the nation's leading authority on organized philanthropy, connecting nonprofits and the grantmakers supporting them to tools they can use and information they can trust. The Center maintains the most comprehensive database on U.S. grantmakers and their grants and conducts research on trends in foundation growth, giving, and practice. It also operates education and outreach programs that help nonprofit organizations obtain the resources they need. Its web site receives more than 57,000 visits each day, and thousands of people are served in its five regional learning centers and through its network of 400 funding information centers located in every U.S. state and beyond. For more information, visit foundationcenter.org or call (212) 620-4230.

\section{Source for all data:}

The Foundation Center

For more information about this advisory, contact communications@foundationcenter.org. 